> Tips om medisinsk litteratur, andre bøker, filmer og elektroniske medier som bør anmeldes, sendes tidsskriftet@legeforeningen.no

\section{Oversiktlig om norsk psykoterapeutisk landskap}

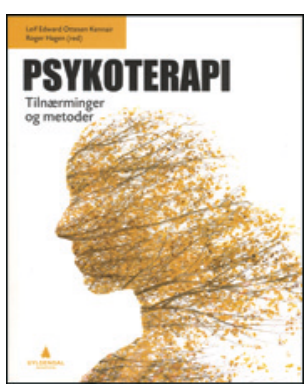

Leif Edward Ottesen Kennair,

Roger Hagen, red.

Psykoterapi

Tilnærminger og metoder. 379 s, tab, ill. Oslo

Gyldendal Akademisk, 2014. Pris NOK 469

ISBN 978-82-05-45853-6

Forfatterne har lykkes med dette ambisiøse bokprosjektet som viser bredden i det norske psykoterapeutiske landskapet. Den strukturerte oppbygningen med teori, begreper og praktiske eksempler gir leseren en opplevelse av å se inn i selve terapirommet og forstå det som skjer på de ulike metodenes egne premisser. Alle som utdanner seg innen psykoterapi eller driver med terapeutiske samtaler i en eller annen form, vil berikes av å lese denne boken. Det samme gjelder de som studerer, underviser eller veileder i psykoterapi, i tillegg til faglige ledere innen psykisk helsevern.

Første del er en innføring i behandlingsforskning og vanskelighetene med å vite hva som måles, og hva som virker i psykoterapi. En del lesere vil nok finne det vanskelig å slutte seg til redaktørenes definisjon av psykoterapi som en form for psykoteknologi. For øvrig er innholdet nøytralt presentert uten spissformuleringer.

Kjennetegn ved en god terapeut blir belyst og vurdert, uavhengig av terapeutisk metode. Det vises til forskning som fremhever at egenskaper ved terapeuten er like viktig som egenskaper ved metoden. Dette danner et bakteppe for den andre delen hvor forfatterne beskriver hele 17 ulike terapeutiske metoder for individuell terapi med voksne. Jeg savner begrunnede utvalgskriterier for hvorfor nettopp disse metodene er valgt fremfor andre. For øvrig styrkes den faglige nøytraliteten ved at man ikke gjør noe forsøk på å evaluere eller sammenlikne de ulike metodene. Det at ledende forskere og klinikere får presentere sine psykoterapeutiske metoder på egne premisser gir tillit til at de fremstilles på riktig måte.

I den andre delen blir det redegjort for den enkelte metodes historiske utvikling, begreper, forståelse av psykopatologi, sentrale terapeutiske prosesser og teknikker, struktur og behandlingsmål. Hvert kapittel avsluttes med forskningsresultater på metoden slik at leseren får et grunnlag for å vurdere effektivitet og anvendbarhet. Par- og familieterapi behandles i egne kapitler, og det hele avsluttes med en beskrivelse av både dynamisk og kognitiv gruppeterapi.

Jeg anbefaler boken til alle som vil utvide sine kunnskaper og forståelse av terapi, metoder og prosesser. Den gir økt innsikt i de ulike metodenes særpreg og vil bidra i debatten om det faglige innholdet i psykoterapiutdanning og psykoterapeutisk praksis.

Torbjørn Tvedten

Psykiater, Senter for terapi og veiledning Skien

\section{Nevrologisk tungvekter i ny utgave}

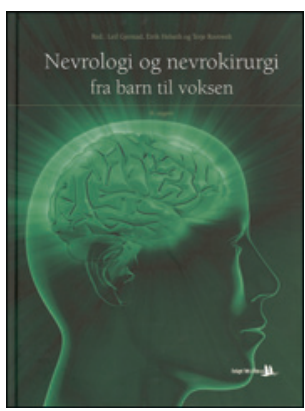

Leif Gjerstad, Eirik Helseth,

Terje Rootwelt, red.

Nevrologi og nevrokirurgi fra barn til voksen

6. utg. 719 s, tab, ill. Drammen: Forlaget Vett

\& Viten, 2014. Pris NOK 998

ISBN 978-82-412-0709-9

Min erfaring er at stadig flere medisinstudenter sverger til lettvinte, kjappe løsninger som At a glance- og Made ridiculously simpleseriene, slik at de får med seg mest mulig relevant pensum på færrest mulig boksider. Den sjette utgaven av den norske læreboken i nevrologi er ingen slik bok. Boken er på hele 719 sider fordelt på 46 kapitler, og vekten tilsvarer vekten av to menneskehjerner. Den kan derfor trygt defineres som en nevrologisk tungvekter.

I forordet beskrives boken som «hovedverket innen norsk nevrologi og nevrokirurgi», og retter seg mot «alle typer studenter og helsepersonell med interesse for nevrologi og nevrokirurgi». Boken er skrevet av forfattere som er sentrale aktører i det norske nevrologi- og nevrokirurgimiljøet, og dekker de fleste aspektene innen nevrofagene - selv om kapitlet Nevropsykologisk undersøkelse har forsvunnet i denne utgaven.

Generelt er boken godt illustrert med flere flotte bilder og illustrasjoner, men bildekvaliteten er varierende og kunne vært frisket opp enkelte steder. Språk og detaljnivå varierer i de ulike kapitlene, sistnevnte uavhengig av tilstandens viktighet. Videre er det ikke henvisning mellom de ulike kapitlene, og noen steder brukes ulike benevnelser om de samme tilstandene, men sånn må det kanskje være slik boken er oppbygd. Undertegnede irriterer seg også over enkelte særskrivninger og trykkfeil. I tillegg er det uheldig at (antatt) klar, fargeløs spinalvæske er farget rød i en illustrasjon (side 142).

Denne utgaven inneholder flere nyskrevne og omskrevne kapitler, blant annet om nevroradiologisk bildediagnostikk og søvnsykdommer. Teksten er godt balansert mellom basiskunnskaper og oppdateringer, og det er mange gode tabeller. Mer kontroversielle tilstander som kronisk utmattelsessyndrom/myalgisk encefalopati (CFS/ME) og nevroborreliose er (bevisst?) ikke viet særlig oppmerksomhet.

Dette er ikke en bok du leser fra perm til perm, men et omfattende og oppdatert oppslagsverk som anbefales både varmt og sterkt til leger og annet helsepersonell som interesserer seg for nevrofagene, og spesielt til medisinstudenter, selv om det finnes (lettere) alternativer. Noen ganger er det faktisk slik at størrelsen teller.

Kashif Waqar Faiz

Avdelingssjef, Avdeling for akuttmedisin

Akershus universitetssykehus 